[Regular Paper]

\title{
Low-temperature Hydrodechlorination of Chlorobenzenes on Palladium-supported Alumina Catalysts
}

\author{
Yoshihito Hashimoto, Yoshio UemichI, and Akimi AyAmE ${ }^{\dagger 1) *}$ \\ Dept. of Applied Chemistry, Muroran Institute of Technology, 27-1 Mizumoto-cho, Muroran, Hokkaido 050-8585, JAPAN
}

(Received June 30, 2004)

\begin{abstract}
Hydrodechlorination of monochlorobenzene (MCB), 1,4-dichlorobenzene (DCB), and 1,3,5-trichlorobenzene (TCB) was carried out on palladium-supported $\gamma$-alumina and alumina Lewis superacid catalysts at $298 \mathrm{~K}$ and ambient pressure in a stream of hydrogen, using a fixed bed flow reactor for the gas-phase reaction and a fixed bed semi-batch reactor for the liquid-phase reaction. Both catalysts showed higher activity for hydrodechlorination in the gas-phase reactions than the platinum catalysts supported on the same carriers. The completely hydrodechlorinated products consisted only of benzene and cyclohexane. Hydrodechlorination of MCB and DCB at $3900 \mathrm{~g} \cdot \mathrm{h} \cdot \mathrm{mol}^{-1}$ resulted in conversions and cyclohexane yields of $100 \%$, and for TCB the cyclohexane yield was also over $95 \%$ with a conversion of $90 \%$. Slight activity decrease of the Pd catalysts due to chlorine accumulation on the catalyst was observed, but the chlorine amount was about one-fourth at $353 \mathrm{~K}$ compared to $298 \mathrm{~K}$ in spite of the remarkable increase in the number of reacted (dechlorinated) molecules, so catalyst deactivation was effectively reduced at higher reaction temperatures. Furthermore, even in the liquid-phase reactions at ambient temperature, which was lower than the reaction temperatures previously used, the palladium-supported catalysts had moderate activity for hydrodechlorination and formed benzene and cyclohexane. The hydrodechlorination of chlorobenzenes probably proceeded through reactions between the hydrogen atoms spilling over from the Pd surface to the alumina carrier surface and the chlorobenzenes adsorbed and activated on the Lewis acid sites of the alumina surface.
\end{abstract}

\section{Keywords}

Hydrodechlorination, Palladium catalyst, Alumina catalyst, Chlorobenzene, Dichlorobenzene,

Trichlorobenzene

\section{Introduction}

Chloroorganic compounds are widely used in the chemical industry, agricultural chemistry, and medical chemistry. These chemicals have provided important contributions to better human life, but some have also caused damage to the environment. The more severe recent environmental problems have increased interest in preserving the global environment.

Chloroorganic compounds, especially dioxins and polychloro-biphenyls, must be removed from the environment, because of their high mutagenicity and carcinogenicity. Establishing a method to eliminate or decontaminate such harmful compounds is very important for the future. Many investigations are continuing on this problem, for example, high-temperature incineration technology ${ }^{1}$, development of new incinerators $^{2)}$, and many microbiological studies ${ }^{3) \sim 6)}$. Partially

\footnotetext{
* To whom correspondence should be addressed.

* E-mail: ak_ayame@mmm.muroran-it.ac.jp

†1) (Present) Professor Emeritus, 6-9-9 Misono-cho, Noboribetsu, Hokkaido 059-0036, JAPAN
}

chlorinated and highly dispersed manganese oxide on a monolayer titania-modified alumina has a high and stable activity for the total oxidation of chlorinated aromatics, in which no chlorinated organic byproducts were detected in the effluent ${ }^{7}$. However, oxidative decomposition or high-temperature incineration of organic chlorides is a temporary solution and also makes little economic sense, because the destruction of aromatic rings seems to have no advantages in the chemical industry or synthetic organic chemistry, because synthesis of organic compounds with aromatic structures from alkanes and alkenes or to aromatize alicyclic alkanes and alkenes requires processes absorbing more energy and economic costs.

The optimum approach is to convert the halogenated aromatics to non-halogenated aromatic or alicyclic compounds without losing the fundamental aromatic structure by catalytic reactions. Catalytic hydrodechlorination of chlorine-substituted aromatics has been reported. Hydrodechlorination of mono-, di-, tri-, and tetra-chlorobenzenes was performed on palladium catalysts at $303 \mathrm{~K}^{8}$. Bimetallic catalysts of platinum 
and vanadium, molybdenum, or tungsten showed good activity for the hydrodechlorination of chlorobenzene at temperatures higher than $413 \mathrm{~K}^{9}$. $\quad$ Liquid-phase hydrodechlorination of monochlorobenzene over palladiumsupported zirconia, magnesia and silica-aluminum phosphate catalysts at $313 \mathrm{~K}$ in methanol showed some different deactivation phenomena depending on the surface characters of the metal oxide carriers, which were caused by the hydrogen chloride generated during the reaction ${ }^{10)}$. Selectivity for benzene of over $98 \%$ was obtained in the liquid-phase hydrodechlorination of monochlorobenzene at 413-473 K on alumina-supported palladium catalyst and palladium-iron bimetallic catalysts, which were prepared by a microwave heating method $^{11)}$. Recently, liquid-phase hydrodechlorination of substituted chlorobenzenes over palladium-supported on aluminum phosphate-silica was found to proceed through electrophilic attack ${ }^{12)}$.

On bifunctional catalysts such as transition metalsupported metal oxides, hydrogen molecules adsorb dissociatively and the produced hydrogen spills over onto the support surfaces ${ }^{13) \sim 15)}$. Especially over metal oxides with strong acidity and/or basicity, the dissociative hydrogen adsorption proceeds heterogeneously, followed by spillover of protons and hydride ions from the metal surface onto basic sites or surface hydroxyl groups and Lewis acid sites on the support, respectively ${ }^{16) \sim 20)}$. Furthermore, since highly dehydrated aluminas have Lewis acid sites formed of aluminum atom vacancies ${ }^{21), 22)}$ and the coordinative bond formation of $\mathrm{Cl}-\mathrm{Al}$ between residual chloride ions and the Lewis acid sites enhances the Lewis acidities of the neighboring vacant aluminum atom sites ${ }^{23) ~ 26)}$, the alumina surfaces modified by chloride ions accelerate the dissociative adsorption of hydrogen on platinum, followed by hydrogen spillover onto the alumina ${ }^{27,28)}$.

We have been studying the selective conversion of polychloro-substituted benzenes to pure benzene, cyclohexene, or cyclohexane without destroying the aromatic structure, using the active spillover of hydrogen. We previously reported that platinum-supported $\gamma$-alumina and alumina solid Lewis superacid (AmLSA) catalysts were active for the hydrodechlorination of monochlorobenzene (MCB), 1,4-dichlorobenzene (DCB) and 1,3,5-trichlorobenzene (TCB) to benzene and cyclohexane at room temperature and ambient hydrogen pressure $^{29)}$. The reactions were promoted by the contribution of the active hydrogen spilling over from the platinum metal surface to the alumina surface. However, the catalysts were deactivated gradually by the irreversible adsorption of chlorine or chloride ions produced during the reaction onto the Lewis acid sites or the Pt surfaces.

In the present study, catalytic hydrodechlorination of chlorobenzenes was carried out on palladium-supported alumina catalysts at $298-353 \mathrm{~K}$ and ambient hydrogen pressure, using a gas-phase and liquid-phase fixed bed reactor.

\section{Experimental}

\section{1. $\mathrm{Pd} / \mathrm{Al}_{2} \mathrm{O}_{3}$ Catalyst}

Aluminas used were JRC-ALO-1 $\left(160 \mathrm{~m}^{2} \cdot \mathrm{g}^{-1} ; 2.4\right.$ $\mathrm{mm}$ spherical particles) and JRC-ALO-6 $\left(180 \mathrm{~m}^{2} \cdot \mathrm{g}^{-1}\right.$; $1.6 \mathrm{~mm}$ spherical particles), which are Reference Catalysts of the Catalysis Society of Japan. Palladium was distributed on the alumina carriers by the impregnation of palladium(II) chloride. Details of the catalyst preparation were similar to those used for the platinum-supported alumina catalysts ${ }^{29), 30)}$. The amounts of palladium were $0.25,0.5$, and $1.0 \mathrm{wt} \%$ of the carrier. Palladium-supported $\gamma$-alumina catalysts prepared from ALO-1 and ALO-6 were named Pd/ALO-1 and Pd/ALO-6, respectively. ALO-6 with small particle size and ALO-1 with large particle size were used in the gas-phase reaction and the liquid-phase reaction, respectively, by considering the characteristics of two types of reactor as described later. The catalytic activities and reaction selectivities of the two types of Pdsupported alumina catalysts were almost identical, as shown in Table 2.

\section{2. Pd/AmLSA Catalyst}

Pre-determined weights of alumina and amorphous palladium were separately put into quartz and Pyrex calcination tubes. The amorphous palladium was previously prepared on a cover glass using a high-frequency $\mathrm{Ar}^{+}$sputtering device. The alumina was dehydrated at $1073 \mathrm{~K}$, then exposed to dry chlorine, followed by outgassing at the same temperature. The chlorine-treated alumina contains strong Lewis acid sites, the so-called "alumina solid Lewis superacid (AmLSA)"26),31),32). After chlorination of the alumina, palladium was deposited on the AmLSA as palladium chloride by the same CVD method as used in the Pt/AmLSA catalyst preparation ${ }^{28), 29), 33)}$, using chlorine and amorphous palladium. The palladium dichloride was finally reduced to metallic palladium by hydrogen at $673 \mathrm{~K}$. The palladium-supported AmLSA catalyst prepared from ALO-6 was named Pd/AmLSA-6. The amount of Pd supported was $0.5 \mathrm{wt} \%$ of the carrier. The surface area of Pd/AmLSA-6 was $171 \mathrm{~m}^{2} \cdot \mathrm{g}^{-1}$, which was about 0.93 of the value of $183 \mathrm{~m}^{2} \cdot \mathrm{g}^{-1}$ for the Pd/ALO- 6 . Treatment of transient alumina in chlorine gas above $973 \mathrm{~K}$ gradually reduced the surface area with complicated phase-transformations ${ }^{34)}$. The AmLSA and the ALO-1 or ALO-6 chlorinated in the catalyst preparation were quite inactive for hydrodechlorination ${ }^{29)}$.

\section{3. Chemicals}

Palladium (99+\%) and palladium(II) chloride (99\%) were supplied by Nilaco Ltd. and Kishida Chem. Co., Ltd., respectively. Chlorine (Nissan Syoji Co., Ltd.; 99.5\%) was distilled three times in a vacuum system 


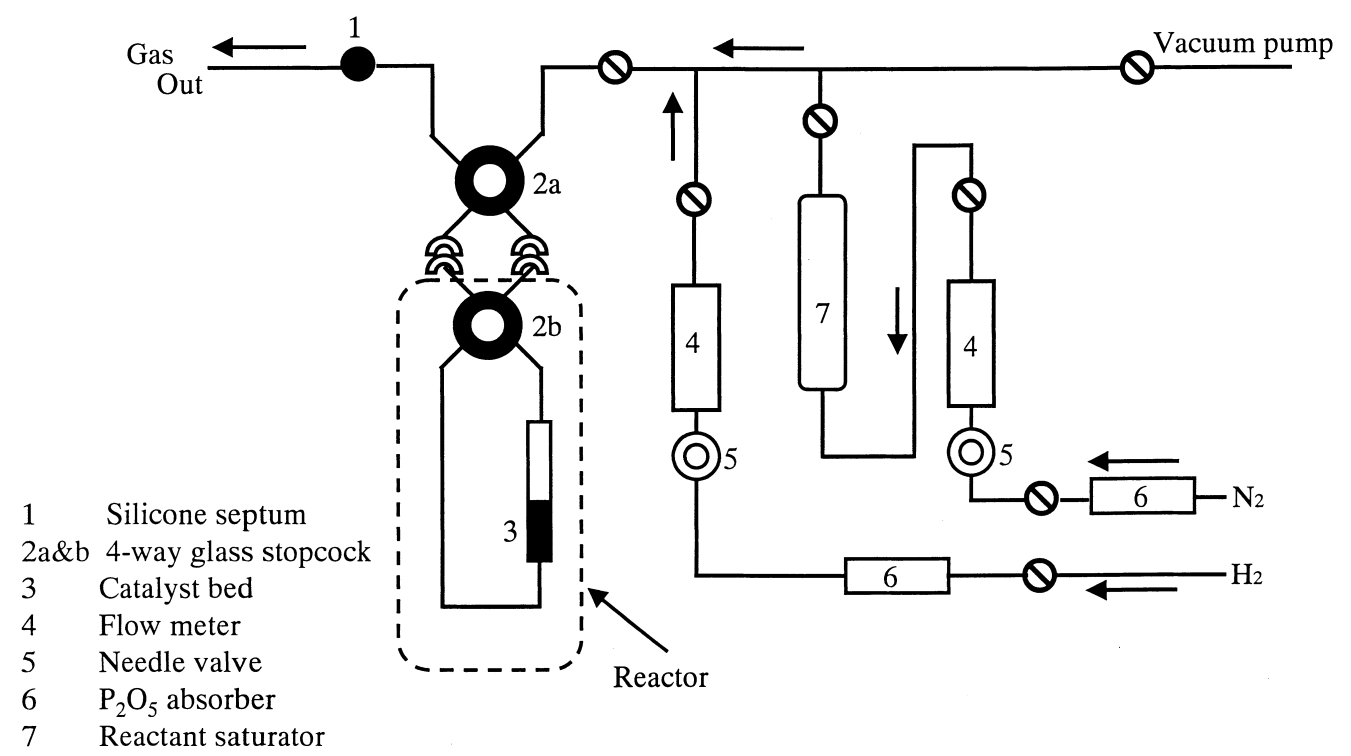

Fig. 1 Fixed Bed Flow Reactor System for Gas-phase Reaction

Table 1 Gas-phase Hydrodechlorinations of DCB on $0.5 \mathrm{wt} \%$ Pd/AmLSA-6 and $0.5 \mathrm{wt} \%$ Pt/AmLSA-6 Catalysts

\begin{tabular}{|c|c|c|c|c|c|c|c|}
\hline \multirow{2}{*}{ Catalyst } & \multirow{2}{*}{$\begin{array}{c}W / F \\
{\left[\mathrm{~g} \cdot \mathrm{h} \cdot \mathrm{mol}^{-1}\right]}\end{array}$} & \multirow{2}{*}{$\begin{array}{l}\text { Reaction } \\
\text { time [min] }\end{array}$} & \multirow{2}{*}{$\begin{array}{c}\text { Conversion } \\
{[\%]}\end{array}$} & \multicolumn{3}{|c|}{ Composition [\%] } & \multirow{2}{*}{$\underset{\left[\mathrm{mol} \cdot \mathrm{h}^{-1} \cdot \mathrm{g}^{-1}\right]}{\mathrm{r}}$} \\
\hline & & & & $\mathrm{C}_{6} \mathrm{H}_{5} \mathrm{Cl}$ & $\mathrm{C}_{6} \mathrm{H}_{6}$ & $\mathrm{C}_{6} \mathrm{H}_{12}$ & \\
\hline \multirow[t]{7}{*}{ Pd/AmLSA-6 } & 780 & 60 & 90.1 & 12.0 & 72.4 & 15.6 & $1.16 \times 10^{-3}$ \\
\hline & & 180 & 77.4 & 7.0 & 80.9 & 12.1 & \\
\hline & 2340 & 60 & 100 & 0 & 61.0 & 39.0 & \\
\hline & & 180 & 100 & 0 & 57.3 & 42.7 & \\
\hline & 3900 & 60 & 100 & 0 & 0 & 100 & \\
\hline & & 180 & 100 & 0 & 0 & 100 & \\
\hline & & 300 & 100 & 0 & 0 & 100 & \\
\hline \multirow[t]{3}{*}{ Pt/AmLSA-6 } & 3900 & 60 & 23.6 & 0 & 0 & 100 & $6.05 \times 10^{-5}$ \\
\hline & & 180 & 17.6 & 14.8 & 0 & 85.2 & \\
\hline & & 300 & 16.9 & 15.5 & 0 & 84.5 & \\
\hline
\end{tabular}

AmLSA-6 was prepared from JRC-ALO-6. Hydrogen flow rate was $4 \mathrm{ml} \cdot \mathrm{min}^{-1}$ and reaction temperature $298 \mathrm{~K}$.

and stored in a 3-liter glass flask. Hydrogen (Air Water Inc.; 99.9999\%) was dehydrated by passing through molecular sieve $4 \mathrm{~A}$ absorbent cooled with liquid nitrogen. Nitrogen (Air Water Inc.; 99.99\%) was dehydrated by passing through a diphosphorus pentaoxidepacked column. Monochlorobenzene (Kanto Chem. Co., Inc.; 98\%) was distilled three times in a vacuum system. 1,4-Dichlorobenzene (>99\%) and 1,3,5trichlorobenzene (99\%) supplied by Tokyo Kasei Kogyo Co., Ltd. were used without further purification.

\section{4. Reaction Systems}

A conventional fixed bed flow reactor consisting of 4 mm i.d. Pyrex glass tubing and a new design of semibatch reactor with gas-liquid-solid phases and a fixed catalyst bed were employed for the gas-phase reaction and the liquid-phase reaction, respectively. The schematic drawing of the apparatus used is shown in Fig. 1. In the liquid-phase reaction, the fixed bed semi-batch reactor was replaced with the reactor port in
Fig. 1. The catalyst weight was $0.25 \mathrm{~g}$. In the gasphase reactor system, chlorobenzenes were introduced into a stream of nitrogen using saturators, which were subsequently mixed with a hydrogen stream. The flow rates of hydrogen and nitrogen were 4 and $20 \mathrm{~m} l$. $\mathrm{min}^{-1}$, respectively. The partial pressures of $\mathrm{MCB}$, $\mathrm{DCB}$, and TCB were 1317,75 , and $20 \mathrm{~Pa}$, respectively. In the fixed bed semi-batch reactor, the hydrogen stream $\left(4 \mathrm{ml} \cdot \mathrm{min}^{-1}\right)$ was introduced below the catalyst bed and the reactants were automatically stirred by the rising hydrogen bubbles. Analysis of the reactants and reaction products was carried out using two gas chromatographs. Although monitoring of the hydrogen chloride produced with process time was required, quantitative analysis was not carried out because simultaneous and accurate analysis was very difficult. Therefore, the formation of hydrogen chloride in the hydrodechlorination was qualitatively tested and confirmed several times using a $1.5 \times 10^{-2} \mathrm{~mol} \cdot l^{-1}$ silver 
Table 2 Gas-phase Hydrodechlorinations of Chlorobenzenes on $0.5 \mathrm{wt} \%$ Pd/alumina Catalysts

\begin{tabular}{|c|c|c|c|c|c|c|c|c|c|}
\hline \multirow{2}{*}{ Reactant } & \multirow{2}{*}{ Alumina } & \multirow{2}{*}{$\begin{array}{c}W / F \\
{\left[\mathrm{~g} \cdot \mathrm{h} \cdot \mathrm{mol}^{-1}\right]}\end{array}$} & \multirow{2}{*}{$\begin{array}{l}\text { Reaction } \\
\text { time [min] }\end{array}$} & \multirow{2}{*}{$\begin{array}{c}\text { Conversion } \\
{[\%]}\end{array}$} & \multicolumn{4}{|c|}{ Composition [\%] } & \multirow{2}{*}{$\begin{array}{c}r^{0}{ }^{0 \mathrm{elm}} \\
{\left[\mathrm{mol} \cdot \mathrm{h}^{-1} \cdot \mathrm{g}^{-1}\right]}\end{array}$} \\
\hline & & & & & $\mathrm{C}_{6} \mathrm{H}_{4} \mathrm{Cl}_{2}$ & $\mathrm{C}_{6} \mathrm{H}_{5} \mathrm{Cl}$ & $\mathrm{C}_{6} \mathrm{H}_{6}$ & $\mathrm{C}_{6} \mathrm{H}_{12}$ & \\
\hline \multirow[t]{2}{*}{$\mathrm{C}_{6} \mathrm{H}_{5} \mathrm{Cl}$} & ALO-6 & 3900 & 60 & 100 & - & 0 & 0 & 100 & \\
\hline & & & 180 & 100 & - & 0 & 0 & 100 & \\
\hline \multirow[t]{8}{*}{$\mathrm{C}_{6} \mathrm{H}_{4} \mathrm{Cl}_{2}$} & ALO-6 & 390 & 60 & 33.8 & - & 35.7 & 61.9 & 2.4 & $8.67 \times 10^{-4}$ \\
\hline & & & 180 & 27.5 & - & 42.6 & 55.3 & 2.3 & \\
\hline & ALO-6 & 780 & 60 & 78.7 & - & 4.5 & 63.3 & 32.2 & $1.01 \times 10^{-3}$ \\
\hline & & & 180 & 77.4 & - & 4.1 & 73.7 & 22.2 & \\
\hline & ALO-1 & 780 & 60 & 80.0 & - & 4.0 & 57.9 & 38.1 & $1.03 \times 10^{-3}$ \\
\hline & & & 180 & 78.1 & - & 5.6 & 69.9 & 24.5 & \\
\hline & ALO-6 & 3900 & 60 & 100 & - & 0 & 0 & 100 & \\
\hline & & & 180 & 100 & - & 0 & 0 & 100 & \\
\hline \multirow[t]{2}{*}{$\mathrm{C}_{6} \mathrm{H}_{3} \mathrm{Cl}_{3}$} & ALO-6 & 3900 & 60 & 91.3 & 2.9 & 0.9 & 62.1 & 34.1 & \\
\hline & & & 180 & 89.4 & 2.7 & 0.8 & 63.0 & 33.5 & \\
\hline
\end{tabular}

Reaction temperature was $298 \mathrm{~K}$ and hydrogen flow rate $4 \mathrm{ml} \cdot \mathrm{min}^{-1}$.

nitrate solution trap, which was connected to the outlet of the fixed bed flow reactor.

\section{Results and Discussion}

\section{1. Reaction on Pd/AmLSA}

Gas-phase hydrodechlorination of DCB using the 0.5 wt $\%$ Pd/AmLSA-6 catalyst was first carried out at 298 $\mathrm{K}$ and $W / F=3900 \mathrm{~g} \cdot \mathrm{h} \cdot \mathrm{mol}^{-1}$ for $3 \mathrm{~h}$. The catalyst indicated high activity for the hydrodechlorination and the only reaction product was cyclohexane, as shown in Table 1. Reduction of the contact time $(W / F)$ resulted in gradual decrease in the conversion of DCB, but the product composition changed to include benzene and MCB as reaction intermediates (Table 1).

The reaction temperature was below the boiling points of the reactants and products, and carbon imbalance was observed between the inlet and outlet of the fixed bed flow reactor. The carbon imbalance resulted from the adsorption and adhesion of reactants and products on the catalyst surfaces and the inside wall of the reactor. However, the carbon-imbalance was almost eliminated by $45 \mathrm{~min}$ after starting the reaction.

Figure 2 shows the dependencies of the conversion and product composition on the $W / F$ for the DCB hydrodechlorination on $0.5 \mathrm{wt} \% \mathrm{Pd} / \mathrm{AmLSA}$ catalyst. With increasing $W / F$, the conversion and the yield of cyclohexane in the product mixture increased, whereas those of benzene and MCB decreased. The change in the product composition with $W / F$ clearly indicated that the hydrodechlorination proceeded in steps $\mathrm{DCB} \rightarrow$ $\mathrm{MCB} \rightarrow \mathrm{C}_{6} \mathrm{H}_{6} \rightarrow \mathrm{C}_{6} \mathrm{H}_{12}$. The DCB conversion decreased slightly with reaction time at $W / F>780 \mathrm{~g} \cdot \mathrm{h} \cdot \mathrm{mol}^{-1}$ (Table 1), but the apparent conversion remained at $100 \%$ even after $5 \mathrm{~h}$ beyond $1500 \mathrm{~g} \cdot \mathrm{h} \cdot \mathrm{mol}^{-1}$. Since the mild decrease in catalytic activity observed in the short contact time was also observed on the Pd/ALO-6 catalysts, we will discuss the causes of the mild deactivation later.

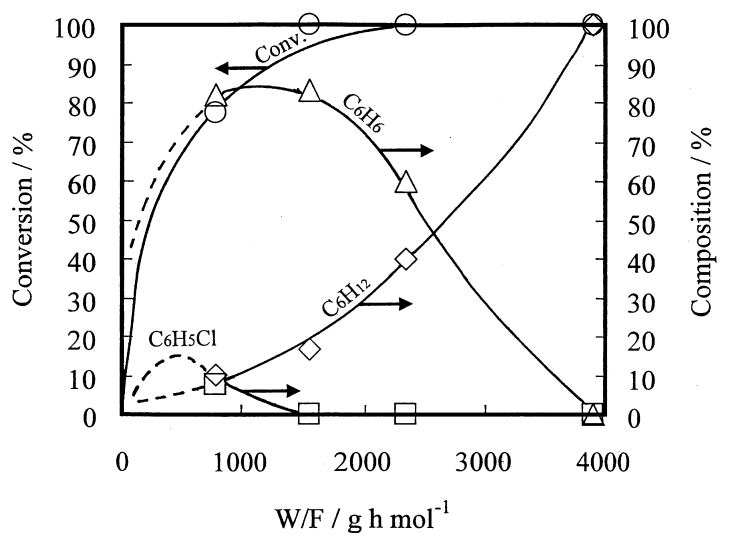

The data were obtained at $5 \mathrm{~h}$ after starting the reaction.

Fig. 2 Dependencies of Conversion and Product Composition on Contact Time in the Gas-phase Hydrodechlorination of DCB on the $0.5 \mathrm{wt} \% \mathrm{Pd} / \mathrm{AmLSA}-6$ Catalyst at $298 \mathrm{~K}$

The results for the $0.5 \mathrm{wt} \% \mathrm{Pd} / \mathrm{AmLSA}-6$ and the 0.5 wt $\% \mathrm{Pt} / \mathrm{AmLSA}$ catalysts, which were obtained at the same reaction conditions, are shown in Table 1 . The catalytic activity of the Pd catalyst was at least 4 times that of the Pt catalyst. The activity decrease of the Pd catalyst with reaction time was significantly smaller than that of the Pt catalyst. The remarkable difference in catalytic activities seems to result from the chemical characteristics of the metals to hydrogen or DCB, since the carrier was identical.

\section{2. Reaction on $\mathrm{Pd} / \mathrm{Al}_{2} \mathrm{O}_{3}$}

The toxicity of chlorine-substituted benzene derivatives increases with the number of chlorine atoms. Complete dechlorination of polychlorobenzene derivatives such as PCB and dioxins is one of the most important technologies in the environmental chemistry field. The present study investigated the hydrodechlorination of model molecules $\mathrm{MCB}$ and TCB compared with $\mathrm{DCB}$, to assess the difficulty of dechlorination 


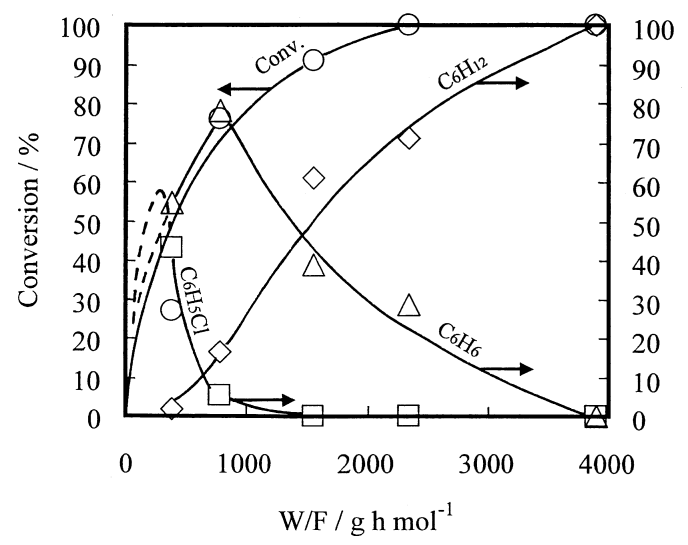

The data were obtained at $5 \mathrm{~h}$ after starting the reaction.

Fig. 3 Dependencies of Conversion and Product Composition on Contact Time in the Gas-phase Hydrodechlorination of DCB on the $0.5 \mathrm{wt} \%$ Pd/ALO-6 Catalyst at $298 \mathrm{~K}$

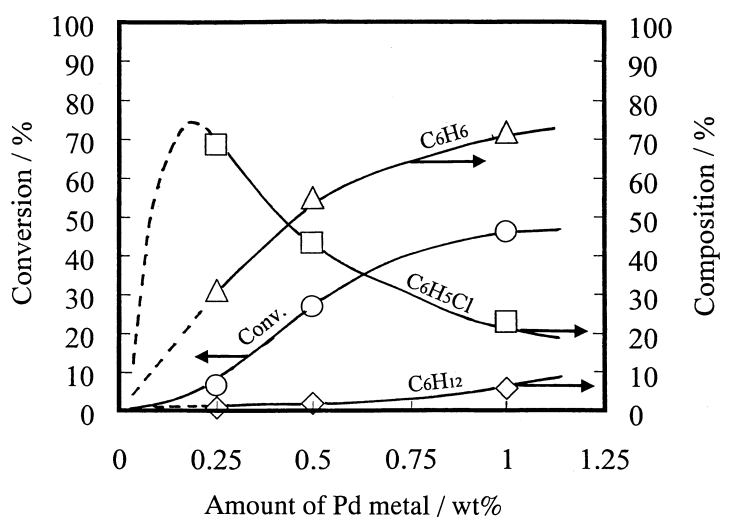

The data were obtained at $5 \mathrm{~h}$ after starting the reaction.

Fig. 4 Variations of Conversion and Product Composition with Amount of Pd in the Gas-phase Hydrodechlorination of DCB on the Pd/ALO-6 Catalyst at $298 \mathrm{~K}$ and $W / F=$ $390 \mathrm{~g} \cdot \mathrm{h} \cdot \mathrm{mol}^{-1}$

$\mathrm{mol}^{-1}$. The dependence of product composition on $W / F$ was fundamentally similar to that for Pd/AmLSA6 catalyst (Fig. 2), but more rapid reduction in the benzene content was observed with $W / F$ than the Pd/AmLSA-6. Probably a benzene- $\pi$-complex forms between the benzene planar molecule and the strong Lewis acid site of the AmLSA, and the coordinated $\pi$ bond is too strong to allow exchange with other basic organic molecules ${ }^{26), 31), 32)}$. Consequently, the hydrogen spillover rate from the Pd to the AmLSA surface or the cyclohexane formation would be reduced by the formation of the $\pi$-complex.

Figure 4 shows the change in the conversion and product composition at $5 \mathrm{~h}$ with the amount of $\mathrm{Pd}$ supported on ALO-6. Increased Pd promoted DCB hydrodechlorination and the product composition gradually shifted to the highly hydrogenated product. These results are due to the increase in the number of hydrogen atoms activated on the Pd surface, because the weight of the ALO-6 carrier used was almost unchanged, i.e., the number of DCB molecules activated on the ALO-6 surface is considered to be almost constant.

Table 3 also shows that the catalytic activity for DCB hydrodechlorination at $298 \mathrm{~K}$ decreased gradually with reaction time. The deactivation was observed even if the amount of Pd was increased to $1.0 \mathrm{wt} \%$. However, when the reaction temperature was raised to $353 \mathrm{~K}$, the deactivation of the Pd catalyst was remarkably reduced. This effect seems to be due to the increases in the migration rate of spillover hydrogen and in the desorption of adsorbed chlorine with higher reaction temperature. Also, the effective reduction in residence times of the reactant and product molecules adsorbed on the alumina surface might be involved.

The amounts of chlorine remaining on the Pd/ALO-6 
Table 3 Conversions and Product Compositions Obtained from DCB Hydrodechlorination on Pd/ALO-6 Catalysts with Different Amounts of $\mathrm{Pd}$ at $W / F=390 \mathrm{~g} \cdot \mathrm{h} \cdot \mathrm{mol}^{-1}$ and at 298 and $353 \mathrm{~K}$

\begin{tabular}{|c|c|c|c|c|c|c|}
\hline \multirow{2}{*}{$\begin{array}{l}\text { Supported } \\
\text { Pd [wt } \%]\end{array}$} & \multirow{2}{*}{$\begin{array}{l}\text { Reaction } \\
\text { temp. }[\mathrm{K}]\end{array}$} & \multirow{2}{*}{$\begin{array}{l}\text { Reaction } \\
\text { time [min] }\end{array}$} & \multirow{2}{*}{$\begin{array}{c}\text { Conversion } \\
{[\%]}\end{array}$} & \multicolumn{3}{|c|}{ Composition [\%] } \\
\hline & & & & $\mathrm{C}_{6} \mathrm{H}_{5} \mathrm{Cl}$ & $\mathrm{C}_{6} \mathrm{H}_{6}$ & $\mathrm{C}_{6} \mathrm{H}_{12}$ \\
\hline \multirow[t]{4}{*}{0.25} & 298 & 60 & 13.4 & 70.7 & 29.1 & 0.2 \\
\hline & & 180 & 9.5 & 74.7 & 24.9 & 0.4 \\
\hline & 353 & 60 & 74.7 & 4.8 & 49.2 & 46.0 \\
\hline & & 180 & 72.3 & 7.7 & 44.6 & 47.7 \\
\hline \multirow[t]{4}{*}{0.5} & 298 & 60 & 33.8 & 35.7 & 61.9 & 2.4 \\
\hline & & 180 & 27.5 & 42.6 & 55.3 & 2.3 \\
\hline & 353 & 60 & 75.3 & 4.8 & 44.7 & 50.3 \\
\hline & & 180 & 78.6 & 7.3 & 44.4 & 48.3 \\
\hline \multirow[t]{4}{*}{1.0} & 298 & 60 & 52.0 & 20.5 & 72.9 & 6.6 \\
\hline & & 180 & 43.5 & 26.1 & 68.6 & 5.3 \\
\hline & 353 & 60 & 93.0 & 0.7 & 8.1 & 91.2 \\
\hline & & 180 & 92.3 & 1.0 & 11.7 & 87.3 \\
\hline
\end{tabular}

catalyst before and after the DCB hydrodechlorination were measured using the Volhard method ${ }^{35)}$. The chlorine content of the fresh catalyst, $6.24 \times 10^{-4} \mathrm{~mol}$. g-cat ${ }^{-1}$, was attributable to the palladium(II) chloride used as a palladium source in the catalyst preparation. After DCB hydrodechlorination for $3 \mathrm{~h}$ at $W / F=390$ $\mathrm{g} \cdot \mathrm{h} \cdot \mathrm{mol}^{-1}$ and $298 \mathrm{~K}$, the chlorine content increased to $9.13 \times 10^{-4} \mathrm{~mol} \cdot \mathrm{g}^{-\mathrm{cat}^{-1}}$. Therefore, the amount of chlorine adsorbed during the reaction was $2.89 \times 10^{-4}$ $\mathrm{mol} \cdot \mathrm{g}_{\text {-cat }}{ }^{-1}$. This value $\left(0.723 \times 10^{-4} \mathrm{~mol} / 0.25 \mathrm{~g}\right.$-cat $)$ was only $2 \%$ of the total chlorine, $3.71 \times 10^{-3} \mathrm{~mol}$, estimated from the mole number of DCB reacted and the product composition. On the other hand, the adsorbed chlorine $\left(1.90 \times 10^{-4} \mathrm{~mol} / 0.25 \mathrm{~g}\right.$-cat $)$ on the Pt/ALO-6 catalyst after reaction at $3900 \mathrm{~g} \cdot \mathrm{h} \cdot \mathrm{mol}^{-1}$ for $3 \mathrm{~h}$ was about $60 \%$ of the total chlorine $\left(3.2 \times 10^{-4} \mathrm{~mol}\right)$ produced during the reaction, and was the origin of the violent catalyst deactivation of the $\mathrm{Pt}$ catalys $\mathrm{t}^{29)}$. By comparing the catalyst deactivation phenomenon and the accumulated chlorine for Pd/ALO-6 with the values for the Pt/ALO-6 catalysts, the affinity of Pd for chlorine was estimated to be smaller than that between $\mathrm{Pt}$ and chlorine. In the presence of hydrogen, chlorine or chlorine ion was more difficult to retain on the Pd catalyst than on the Pt catalyst even at room temperature. Consequently, the Pd/ALO-6 catalyst is considered to have higher activity for hydrodechlorination than the Pt/ALO-6 catalyst.

However, the retention of the small amount of chlorine indicates that the Pd catalyst was also deactivated extremely slowly, although apparently maintaining high activity after 3-5 h. In addition, the chlorine adsorbed on the Pd catalyst after hydrodechlorination at $353 \mathrm{~K}$ for $3 \mathrm{~h}$ was $7.05 \times 10^{-4} \mathrm{~mol} \cdot \mathrm{g}^{-\mathrm{cat}^{-1}}$, but the accumulated amount was only $0.81 \times 10^{-4} \mathrm{~mol} \cdot \mathrm{g}_{\text {-cat }}{ }^{-1}$, which was about $28 \%$ of that at $298 \mathrm{~K}$, in spite of the considerable increase in mole number of the reacted DCB. This suggests that deactivation of the Pd catalyst can be avoided by raising the reaction temperature

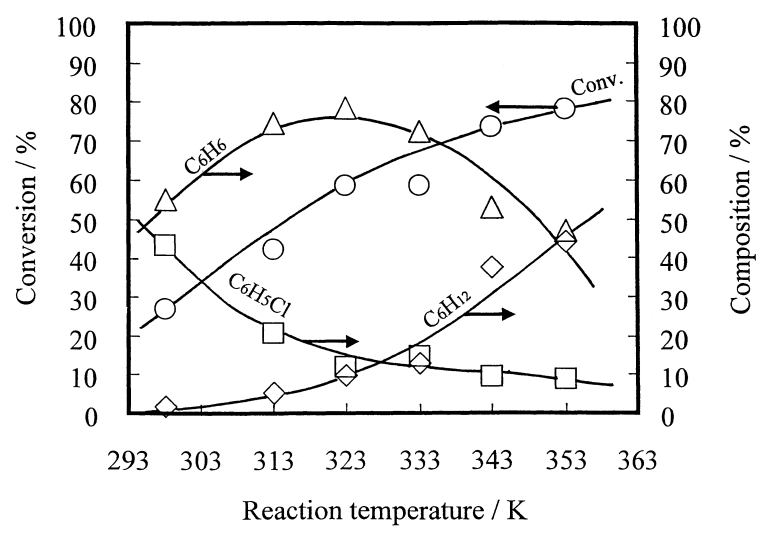

The data were obtained at $5 \mathrm{~h}$ after starting the reaction.

Fig. 5 Variations of Conversion and Product Composition with Reaction Temperature in the Gas-phase Hydrodechlorination of DCB on the $0.5 \mathrm{wt} \%$ Pd/ALO-6 Catalyst at $W / F=390 \mathrm{~g} \cdot \mathrm{h} \cdot \mathrm{mol}^{-1}$ and Hydrogen Flow Rate $4 \mathrm{ml} \cdot \mathrm{min}^{-1}$

carefully.

Figure 5 shows the reaction temperature dependencies of the conversion and product composition for the DCB hydrodechlorination. The conversion increased with higher reaction temperature and the product composition shifted to the highly hydrogenated products. At about $323 \mathrm{~K}$, benzene formation reached the maximum and MCB formation decreased with further increases in temperature. A similar conclusion can be also drawn from the results in Table 3 .

\section{3. Hydrogen-spillover Phenomenon at Ambient Temperature}

Previously, we reported that the deactivation of the AmLSA catalyst during the isopropylation of benzene with propylene at ambient temperature was completely reduced, without changes in product composition, by supporting Pt on AmLSA and adding hydrogen to the stream of propylene and nitrogen ${ }^{30}$. The reduction 
effect was due to the spillover of hydrogen from the $\mathrm{Pt}$ surface to the Lewis acid sites of the AmLSA surface: the desorption of polyisopropylbenzenes adsorbed on the Lewis acid sites was promoted by the spillover of hydrogen atoms. Also, the existence of spillover hydrogen at room temperature was confirmed using the measurements of IR spectrum changes of adsorbed pyridine and hydroxyl groups on the hydrogen-reduced $\mathrm{Pt} / \mathrm{AmLSA}$ samples ${ }^{28)}$. In the present study, two new experiments were performed to investigate the hydrogen-spillover phenomenon on the Pd/ALO-6 catalysts at ambient temperature.

DCB hydrodechlorination through the catalyst beds adjusted to constant $2.7 \times 10^{-4} \mathrm{~g}$ supported Pd was carried out, using the same catalysts as employed in the determination of the data shown in Fig. 4. In this case, the catalyst weight (volume) ratios of $0.25,0.50$, and $1.0 \mathrm{wt} \% \mathrm{Pd} / \mathrm{ALO}-6$ catalysts packed into the reactor were 4/2/1. The DCB conversions obtained at 298 $\mathrm{K}$ and (weight of $\mathrm{Pd}) / F=390 \mathrm{~g} \cdot \mathrm{h} \cdot \mathrm{mol}^{-1}$ were 84.3, 70.9 , and $46.1 \%$ on the $0.25,0.50$, and $1.0 \mathrm{wt} \%$ Pd catalysts, respectively. The product composition shifted to highly hydrogenated products with increased conversion. If the amount of hydrogen activated on $2.7 \times 10^{-4}$ $\mathrm{g} \mathrm{Pd}$ is sufficiently large and almost constant, the increases in DCB conversion and highly hydrogenated products were probably due to the increase in the number of DCB molecules activated on the ALO-6 carrier. These results suggest that the hydrodechlorination proceeds through the reactions on the carrier surface between the hydrogen atoms, which spilled over from the Pd surface to the carrier surface, and the activated DCB molecules.

Hydrodechlorination of DCB at $298 \mathrm{~K}$ for $3 \mathrm{~h}$ was also performed through the two-bed continuous reactor comprised of a $1.0 \mathrm{wt} \%$ Pd/ALO- 6 catalyst bed of 0.25 $\mathrm{g}$ packed directly on the ALO- 6 carrier bed of $0.15 \mathrm{~g}$ in the downward side, where the ALO-6 used as the carrier bed was pre-treated using $\mathrm{HCl}$ solution in the same way as the Pd/ALO- 6 catalyst preparation. The DCB conversion data are shown in Fig. 6, compared to the data for the $1.0 \mathrm{wt} \% \mathrm{Pd} / \mathrm{ALO}-6$ of $0.25 \mathrm{~g}$ only. Conversion through the two-bed continuous reactor was higher by about $10 \%$ compared to the $\mathrm{Pd} / \mathrm{ALO}-6$ catalyst only and the product composition of $\mathrm{MCB} / \mathrm{C}_{6} \mathrm{H}_{6} / \mathrm{C}_{6} \mathrm{H}_{12}$ changed from $25.8 / 71.1 / 3.1$ to $22.8 / 72.7 / 4.5$. These results strongly suggest that the hydrogen atoms activated on the Pd surface spill over from the Pd surface of the Pd/ALO- 6 catalyst to the ALO-6 surface of the carrier bed at the downward side and promote the hydrodechlorination of DCB activated on the ALO- 6 surfaces of the carrier bed.

The four experimental findings suggest that the spillover of hydrogen atoms from the Pd and Pt surfaces to the alumina surfaces modified by chlorine takes place even at ambient temperature.

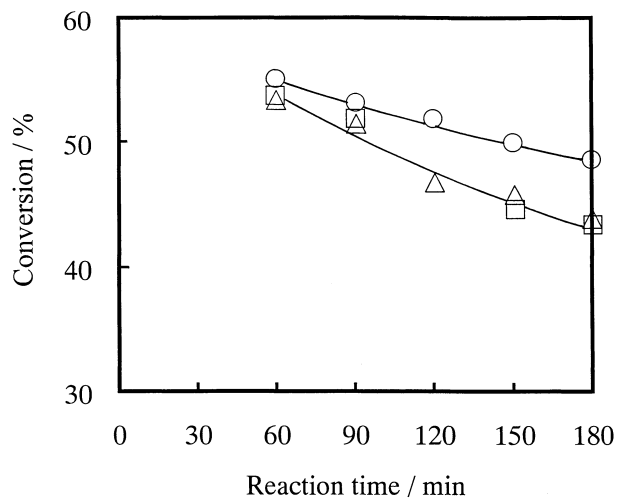

(O): The two-bed continuous reactor was comprised of the 1.0 wt $\%$ Pd/ALO- 6 catalyst bed of $0.25 \mathrm{~g}$ packed directly on the ALO- 6 carrier bed of $0.15 \mathrm{~g}$ in the downward side. ( $\square$ ) and $(\triangle)$ : The $1.0 \mathrm{wt} \% \mathrm{Pd} / \mathrm{ALO}-6$ catalyst bed of $0.25 \mathrm{~g}$ only.

Fig. 6 Hydrodechlorination of DCB Using Two Different Reactors at $298 \mathrm{~K}$ and $W / F=390 \mathrm{~g} \cdot \mathrm{h} \cdot \mathrm{mol}^{-1}$

\section{4. Liquid-phase Reaction}

The palladium-supported alumina catalysts were very active for the gas-phase hydrodechlorinations at low temperatures. Since the reaction temperature adopted here was near room temperature and lower than the boiling points of reactants and products, the handling of the fixed bed flow reactor in gas-phase reactions was not always easy. Therefore, an adequate liquid-phase reactor system may be better than the gas-phase reaction system. One of the authors has developed a conventional fixed bed semi-batch reactor that is available for three-phase catalytic reactions comprising gaseous reactant, liquid reactant, and granular solid catalyst of $4-6 \mathrm{~mm}$ in diameter ${ }^{36}$. One such modified reactor was used in the present and preceding studies of the liquid-phase hydrodechlorination of chlorobenzenes $^{29)}$. Figure 7 and Table 4 show the results for MCB, DCB and TCB obtained in the liquidphase reaction at $298 \mathrm{~K}$ using the fixed bed semi-batch reactor, using a $5-\mathrm{m} l$ aliquot of the reactants diluted by $n$-hexane as solvent $\left(0.8 \mathrm{~mol} \cdot l^{-1}\right)$, hydrogen stream of 4 $\mathrm{m} l \cdot \mathrm{min}^{-1}$, and $0.25 \mathrm{~g} \mathrm{Pd} / \mathrm{ALO}-1$ catalyst. The conversions of MCB, DCB, and TCB after $3 \mathrm{~h}$ were 10.4, 4.5, and $1.0 \%$, respectively. Although only benzene and cyclohexane were obtained in the hydrodechlorination of MCB, the formation of MCB was observed in the reaction of $\mathrm{DCB}$. $\mathrm{MCB}$, benzene, and cyclohexane were formed in the reaction of TCB, but DCB was not detected. For the DCB hydrodechlorination, duplicate data are plotted in Fig. 7. The results demonstrate the reproducibility of the present experimental work.

The average initial elimination rate of DCB, $3.4 \times$ $10^{-4} \mathrm{~mol} \cdot \mathrm{h}^{-1} \cdot \mathrm{g}^{-1}$, in the liquid-phase reaction (Table 4) can be compared with $1.0 \times 10^{-3} \mathrm{~mol} \cdot \mathrm{h}^{-1} \cdot \mathrm{g}^{-1}$ obtained in the gas-phase reaction, as shown in Table 2 . The 
difference between the two elimination rates seems to depend on differences in the mass transfer effects of the adsorbed hydrogen (or spillover hydrogen) within the boundary layers (including the depth) between gas and solid or between liquid and solid. The mass transfer effects including the reactants and products would also be reduced with higher reaction temperature and/or adequate stirring of the liquid mixture. In practice, the DCB conversion and the cyclohexane yield increased with higher rates of hydrogen stream. Consequently, the results in Table $\mathbf{4}$ show that the data are quite reasonable: that is, the Pd/ALO- 1 catalyst has sufficiently high activity even in the liquid-phase reaction system.

MCB hydrodechlorination carried out without using $n$-hexane resulted in conversion of only $0.3 \%$, and the elimination rate of $\mathrm{MCB}, 2.0 \times 10^{-4} \mathrm{~mol} \cdot \mathrm{h}^{-1} \cdot \mathrm{g}^{-1}$, was one-thirteenth of the $2.6 \times 10^{-3} \mathrm{~mol} \cdot \mathrm{h}^{-1} \cdot \mathrm{g}^{-1}$ for the reaction using $n$-hexane solvent. This decrease in the reaction rate is due to the solvent effects on the catalytic reaction.

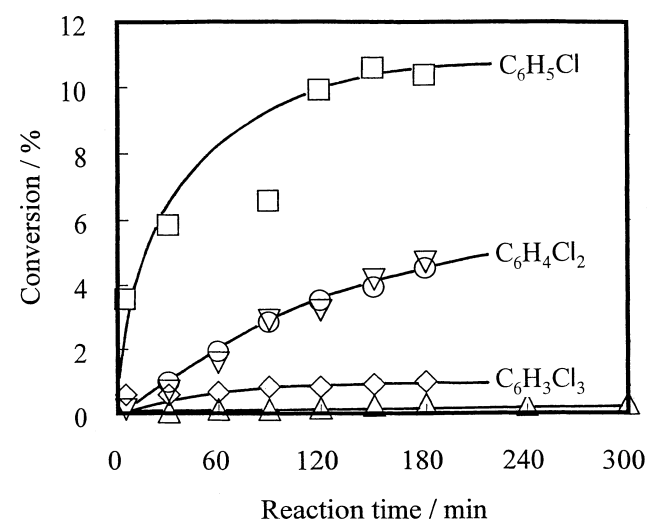

$\bigcirc$ and $\nabla$ are duplicate experimental data for $\mathrm{C}_{6} \mathrm{H}_{4} \mathrm{Cl}_{2}$. $\triangle$ shows the data for the run using $5 \mathrm{~m} l$ of pure $\mathrm{C}_{6} \mathrm{H}_{5} \mathrm{Cl}$ as reactant. Catalyst $0.25 \mathrm{~g}$, reaction temperature $298 \mathrm{~K}$, hydrogen flow rate $4 \mathrm{~m} l \cdot \mathrm{min}^{-1}$, and $5 \mathrm{~m} l$ aliquot of $0.8 \mathrm{~mol} \cdot l^{-1} n$-hexane solution.

Fig. 7 Liquid-phase Hydrodechlorination of Chlorobenzenes on the $0.5 \mathrm{wt} \% \mathrm{Pd} / \mathrm{ALO}-1$ Catalyst

\section{Conclusion}

Pd/AmLSA-6 and Pd/alumina catalysts had sufficiently high activities for the selective hydrodechlorination of chlorobenzenes to benzene and cyclohexane at 298-353 K and ambient pressure of hydrogen. Even in the liquid-phase reaction system, these catalysts functioned effectively and formed hydrodechlorinated products.

The catalytic activities of the Pd-supported alumina catalysts were higher than those of the Pt-supported ones $^{29)}$. In the gas- and liquid-phase reaction systems, the hydrodechlorination rates decreased with higher number of chlorine atoms in the molecule, but the Pdsupported alumina catalysts are considered to be one of the most powerful and effective catalysts for the selective hydrodechlorination of polychloroorganic compounds such as PCBs and dioxins.

The results in Fig. $\mathbf{4}$ and the subsequent experiments showed that the hydrodechlorination of chlorobenzenes consists of reactions between the spillover hydrogen atoms from the $\mathrm{Pd}$ and the chlorobenzenes adsorbed and activated on the Lewis acid sites on the alumina. The Pd surface seems also to promote the formation of spillover hydrogen more effectively than the Pt surface. However, the first step remains unclear: the withdrawal of chlorine from chlorobenzenes by the Lewis acid sites or the nucleophilic attack of the $\mathrm{Cl}-\mathrm{C}$ bond of the chlorobenzenes by the spillover hydrogen (perhaps hydride ion).

Slight activity decrease with time, i.e., catalyst deactivation, was clearly observed at $298 \mathrm{~K}$. Determination of the chlorine amount on the used Pd catalysts proved that the origin of the catalyst deactivation was the accumulation of chlorine or chlorine ions on the catalyst surface. The deactivation of the Pd catalysts proceeded more slowly than for the Pt catalysts; the chlorine amount on the used Pd catalyst was much smaller than that on the Pt catalyst at the same reaction conditions ${ }^{29}$. The characteristics of the deactivation phenomena and the amounts of chlorine on the used catalysts suggest that little chlorine accumulated on the $\mathrm{Pd}$ metal surface, whereas chlorine accumulation took

Table 4 Liquid-phase Hydrodechlorination of Chlorobenzenes on the $0.5 \mathrm{wt} \%$ Pd/ALO-1 Catalyst

\begin{tabular}{|c|c|c|c|c|c|c|}
\hline \multirow{2}{*}{ Reactant } & \multirow{2}{*}{$\begin{array}{c}\text { Conversion } \\
{[\%]}\end{array}$} & \multicolumn{4}{|c|}{ Composition [\%] } & \multirow{2}{*}{$\begin{array}{c}r^{0} \mathrm{elm}^{\mathrm{a})} \\
{\left[\mathrm{mol} \cdot \mathrm{h}^{-1} \cdot \mathrm{g}^{-1}\right]}\end{array}$} \\
\hline & & $\mathrm{C}_{6} \mathrm{H}_{4} \mathrm{Cl}_{2}$ & $\mathrm{C}_{6} \mathrm{H}_{5} \mathrm{Cl}$ & $\mathrm{C}_{6} \mathrm{H}_{6}$ & $\mathrm{C}_{6} \mathrm{H}_{12}$ & \\
\hline $\mathrm{C}_{6} \mathrm{H}_{5} \mathrm{Cl}$ & 10.4 & - & - & 69.6 & 30.4 & $2.6 \times 10^{-3}$ \\
\hline $\mathrm{C}_{6} \mathrm{H}_{4} \mathrm{Cl}_{2}$ & 4.5 & - & 14.3 & 22.4 & 63.3 & $3.4 \times 10^{-4}$ \\
\hline $\mathrm{C}_{6} \mathrm{H}_{3} \mathrm{Cl}_{3}$ & 1.0 & 0 & 3.6 & 2.6 & 93.8 & $6.1 \times 10^{-5}$ \\
\hline $\mathrm{C}_{6} \mathrm{H}_{5} \mathrm{Cl}^{\mathrm{b})}$ & 0.3 & - & - & 100 & 0 & $2.0 \times 10^{-4}$ \\
\hline
\end{tabular}

Catalyst $0.25 \mathrm{~g}$, temperature $298 \mathrm{~K}, 5 \mathrm{ml}$ aliquot of $0.8 \mathrm{~mol} \cdot l^{-1} n$-hexane solution, hydrogen flow rate $4 \mathrm{~m} l \cdot \mathrm{min}^{-1}$ (constant), and reaction time $180 \mathrm{~min}$.

a) $r^{0}$ elm: Average initial reaction rate estimated from the data within the reaction time 60 min, as shown in Fig. 7 .

b) $5 \mathrm{ml}$ monochlorobenzene without solvent was used. 
place both on the Pt and alumina surfaces. Furthermore, the deactivation effect was easily reduced by raising the reaction temperature carefully.

\section{References}

1) Yoshida, N., So-da to Enso, 548, 367 (1995).

2) Tsuboi, H., Nensho Kenkyu, 114, 11 (1998).

3) Boyd, S. A., Zwiernik, M. J., Quensen, J. F., Environ. Sci. Technol., 32, 3360 (1998).

4) Morn, W. W., Kuipers, B., Cullen, W. R., Environ. Sci. Technol., 33, 3579 (1999).

5) Deweerd, K. A., Bedard, D. L., Environ. Sci. Technol., 33, 2057 (1999).

6) Tachibana, S., Mizu, 40, 16 (1998).

7) Liu, Y., Wei, Z., Feng, Z., Luo, M., Ying, P., Li, C., J. Catal., 202, 200 (2001).

8) Balko, E. N., Przybylski, E., Tretini, F. V., Appl. Catal. B. Environmental, 2, 1 (1993).

9) Rao, P. K., Srinivas, S. T., Lakshimi, L. J., Lingaiah, N., Prasad, P. S. S., Appl. Catal. A: General, 135, 201 (1996).

10) Aramendía, M. A., Borau, V., García, I. M., Jiménez, C., Lafont, F., Marinas, A., Marinas, J. M., Urbano, F. J., J. Catal., 187, 392 (1999).

11) Berry, F. J., Smart, L. E., Prasad, P. S. S., Lingaiah, N., Rao, P. K., Appl. Catal. A: General, 204, 191 (2000).

12) Aramendía, M. A., Borau, V., García, I. M., Jiménez, C., Marinas, A., Marinas, J. M., Urbano, F. J., Appl. Catal. B: Environmental, 43, 71 (2003).

13) Baumgarten, E., Lentes-Wagner, C., Wagner, R., J. Mol. Catal., 50, 153 (1989)

14) Ebitani, K., Konishi, H., Hattori, H., J. Catal., 130, 257 (1991).

15) Jaeger, N. I., Schulz-Ekloff, G., Appl. Catal. A: General, 84, 47 (1992).

16) Shishido, T., Hattori, H., Appl. Catal. A: General, 146, 157 (1996).

17) Roessner, F., Roland, U., J. Mol. Catal. A: Chem., 112, 401
(1996).

18) Roessner, F., Braunschweig, T., Roland, U., J. Mol. Catal. A: Chem., 127, 61 (1997).

19) Zhang, A., Nakamura, I., Fujimoto, K., J. Catal., 168, 328 (1997).

20) Hattori, H., Ebitani, K., Hyomen, 32, 308 (1994).

21) Abe, M., Tajika, T., Ayame, A., Takeno, N., Shokubai, 25, 151 (1983).

22) Ayame, A., Abe, M., Kitagawa, T., Omoya, K., Sekiyu Gakkaishi (J. Jpn. Petrol. Inst.), 33, (2), 75 (1990).

23) Basset, J., Mathieu, M. V., Pretre, M., Rev. Chim. Miner., 5, 879 (1958).

24) Gati, G., Knözinger, H., Z. Phys. Chem. Frankfurt am Mein, 78, 243 (1972).

25) Marczewski, M., Derewinski, M., Marinowski, S., Can. J. Chem. Eng., 60, 93 (1983).

26) Ayame, A., Sawada, G., Sato, H., Zhang, G., Ohta, T., Izumizawa, T., Appl. Catal. A: General, 48, 25 (1989).

27) Musso, J. C., Pareta, J. M., Appl. Catal. A: General, 30, 81 (1987).

28) Honda, K., Ayame, A., Nippon Kagaku Kaishi, 375 (1999).

29) Hashimoto, Y., Ayame, A., Appl. Catal. A: General, 250, 247 (2003).

30) Yamada, K., Honda, K., Kitahara, D., Miyamoto, M., Shiga, M., Ayame, A., Sekiyu Gakkaishi (J. Jpn. Petrol. Inst.), 43, (2), 135 (2000).

31) Ayame, A., Izumizawa, T., J. Chem. Soc., Chem. Commun., 645 (1989).

32) Ayame, A., Izumizawa, T., Hyomen, 27, 640 (1989).

33) Ayame, A., Honda, K., "Acid-base Catalysis II," eds. by Hattori, H., Misono, M., Ono, Y., Kodansha Ltd., Tokyo (1994), p. 257.

34) Ayame, A., Ohta, K., Kato, A., Honda, K., Nippon Kagaku Kaishi, 382 (1998).

35) Ayame, A., Izumizawa, T., Kakizaki, H., "Acid-base Catalysis," eds. by Tanabe, K., Hattori, H., Yamaguchi, T., Tanaka, T., Kodansha Ltd., Tokyo (1989), p. 371

36) Kitahara, D., Ayame, A., The 82nd CATSJ Meeting Abstracts, Catal. Soc. Jpn., Matsuyama, Japan (1998), p. 337 (No. 4D810). 
要旨

\section{パラジウム担持アルミナ触媒上でのクロロベンゼン類の低温水素化脱塩素}

橋本 義人, 上道 芳夫, 菖蒲 明己

室蘭工業大学応用化学科, 050-8585 北海道室蘭市水元町 27-1

固定床気相流通反応器と液相固定床半回分式反応器を用い て, $298 \mathrm{~K}$, 常圧の水素気流中で, パラジウム担持 $\gamma$-アルミナ 触媒抒よびパラジウム担持アルミナルイス超強酸触媒上でのモ ノクロロベンゼン (MCB), 1,4-ジクロロベンゼン (DCB), 1,3,5-トリクロロベンゼン（TCB）の水素化脱塩素反応を行っ た。気相反応において, 両触媒は白金担持触媒よりも高い水素 化脱塩素活性を示した。反応生成物はベンゼンとシクロへキサ ンのみであった。接触時間 $3900 \mathrm{~g} \cdot \mathrm{h} \cdot \mathrm{mol}^{-1}$ での MCB, DCBの 反応に挍ける転換率とシクロへキサン収率はともに $100 \%$ であ り，一方 TCBの反応では転換率 $90 \%$ において $95 \%$ 以上のシ
クロヘキサン収率が得られた。これらパラジウム担持触媒は反 応中に生成する塩素の触媒表面への蓄積による活性低下を示し た。 $353 \mathrm{~K}$ の反応に扔ける蓄積塩素量は $298 \mathrm{~K}$ の時の約 $1 / 4$ で あった。すなわち, 反応温度を高くすると触媒の活性低下は効 果的に抑制された。さらに, パラジウム担持触媒は, 常温の液 相反応に扔いても水素化脱塩素に対して適度な活性を示し, ベ ンゼンとシクロヘキサンを生成した。クロロベンゼン類の水素 化脱塩素反応は, パラジウム上で生成しアルミナ表面上にスピ ルオーバーした水素とアルミナ上のルイス酸点に吸着し活性化 されたクロロベンゼンとの間の反応であると推定された。 